\title{
THE EFFECT OF TRAINING AND HUMAN RESOURCES DEVELOPMENT ON EMPLOYEE PERFORMANCE IN THE SYAHBANDAR OFFICE OF TANJUNG PERAK SURABAYA THROUGH COMPETENCY
}

\author{
Dwi Ambar Anggraini ${ }^{1}$, Drs. Ec. I Nyoman Sudapet ${ }^{2}$, Hamzah Denny Subagyo $^{3}$ \\ Dwiambar03@gmail.com¹, Nyomansudapet1@gmail.com²,Dennysalon@gmail.com³ \\ Departement of Management, Faculty of Economics and Business, Narotama University \\ Jl. Arif Rahman Hakim 51, Surabaya, Indonesia, 60117
}

\begin{abstract}
The purpose of this study is to find out the effect of training and development of human resources on employee performance through competence. This research is quantitative research. With a population of 143 employees. Data collection techniques using a questionnaire. The analysis technique used is Partial Least Square (PLS). The results of this study indicate that there is a significant influence between the Training variable (X1) on Competence (Y1) with the results of the hypothesis test $\mathrm{p}$-value of 0.000 and $\mathrm{t}$ value of 4.091 , there is a significant influence between the variables of Human Resource Development (X2) on Competence ( Y1) with the results of hypothesis testing p-value of 0.000 and $t$ value of 11,494, there is a significant influence between Training variables (X1) on Employee Performance (Y2) with the results of hypothesis testing p-value 0,000 and $t$ value of 5,273, influence significant between the variables of Human Resource Development (X2) on Employee Performance (Y2) with the results of hypothesis testing p-value of 0,000 and t value of 4,614 and there is a significant influence between Competency variables (Y1) on Employee Performance (Y2) with the results of hypothesis testing $\mathrm{p}$-value of 0.034 and $\mathrm{t}$ value of 1.835 .
\end{abstract}

Keywords : Human Training, Human Resource Development, Employee Performance, Human Competence.

\section{INTRODUCTION}

One important asset that must be considered by a company is its human resources, because it is the company's expectation to achieve the stated goals. To achieve these goals with the development of the company, the company must have experienced some problems in its HR. These problems include, the decline in the quality of work, changes in policy, and the entry of new technologies, and so forth. So that some of these problems are needed efforts to improve and improve the competence of human resources. Improvement and improvement of these competencies can be realized through training programs and human resource development.

Training and development programs also have a very important role for a company. Where training and development is directly related to human resources, so that if the human resources have passed this stage, then they can be assured that they have gained more expertise than those who do not pass training and development programs. A training and development program must be planned and arranged appropriately, to suit the needs of employees and the company. This can realize the purpose of the company that coincides with the goals of individual employees.

Training itself is a planned effort from the organization to improve the knowledge, skills and abilities of employees. The implementation of the training certainly must be carried out consistently by the company in order to realize the company's goals and the goals of the employees themselves. The training component is prepared based on the needs of employees and companies, with the hope that the training activities can improve employee competencies. While the development of human resources in the organization is a matter that needs to be considered too, because through human resource development it is expected that its performance will also achieve good results. Human resource development programs will benefit organizations and employees themselves, both from within the organization and from outside the organization, for example through non-formal educational institutions to support formal education programs.

Competence is the ability of someone who can breakthrough which includes knowledge, skills, and attitudes in completing a job or task in accordance with the determined performance. In this case, every employee, both new and old, must have different levels of competence in carrying out their work. So that efforts are needed to improve and improve so that the competencies of each employee can be equal in accordance with the standards of company needs. Company competencies in the company can be improved through training and education programs. In this case, the 
implementation of the program is expected to improve employee competency which consists of attitudes, skills, knowledge and professionalism of employees with the aim of improving employee performance.

Performance is a benchmark used by the company as a reference in assessing the work of employees. Employees must carry out their work in accordance with company requirements. Therefore, employees are required to have good competence in order to achieve company goals and individual goals. The problem of employee performance will not be separated from the competence of employees, because the company requires competent employees to be able to support the company's goals and can provide maximum performance.

The Syahbandar Office of Tanjung Perak Surabaya has the mission of realizing the professionalism of human resources of the Ministry of Transportation apparatus and also producing education and training programs that support the improvement of employee competencies so as to create compatibility between the competencies possessed by employees and the position requirements set by the organization. In an effort to achieve the mission in the Syahbandar Office, carried out a training and development program to lead to increased work competencies.

From the background above, the authors are interested in conducting research on the implementation of training and development programs in order to lead to improving employee work competencies. For this reason, the author takes the title of research, namely the Effect of Training and Development of Human Resources on Employee Performance in the Syahbandar Office of Tanjung Perak Surabaya through Competency.

\section{LITERATURE REVIEW}

\section{Human Resource Management}

To plan, manage and control human resources a managerial tool is needed called human resources. Every HRM activity requires thinking and understanding of what will work well and what doesn't.

\section{Training (X1)}

Training is an activity to improve one's work ability in relation to economic activity. The purpose of training is to help employees understand a knowledge, in order to improve the skills, skills and attitudes needed by organizations within the company to achieve its goals.

Training indicators according to (Mangkunegara, 2013) in books (Sudaryo, Aribowo, \& Dr. Nunung Ayu Sofiati, 2018), including:

a. $\quad$ Training Instructors

b. ParticipantsTraining

c. Materials Training

d. Methods

\section{Human Resource Development (X2)}

Development of good human resources new and old needs to be done in a planned and sustainable manner.

Therefore an employee development program is needed. The development of this employee is important because of the demands of work and position as a result of advances in science and technology and increasingly intense competition among similar companies.

According to the above understanding, it can be concluded the indicators of human resource development:

a. Level of expertise for employees

b. Identification of interest in employee

c. Identification of potential employees

d. Motivation

\section{Competence (Y1)}

(Wirawan, 2015) Competence is a special ability that is very complex. From the vademic work prepared by the Ministry of Manpower of various countries, there are thousands of competencies ranging from the competence of doctors, teachers, soldiers, and police to the competence of baby sitters whose job is to care for babies.

Competency indicators according to the above understanding are as follows:
a. Skill
b. Ability
c. Experience
d. Work Effectiveness
e. Thinking Power 


\section{Employee Performance (Y2)}

Performance comes from the word job performance or actual performance which means work performance or actual achievement achieved by someone.

Employee performance indicators according to Agus Dharma (2004: 24) include:
a. Quantity
b. Quality
c. On Time

\section{Research Concept Framework}

Figure 1: Research Concept Framework

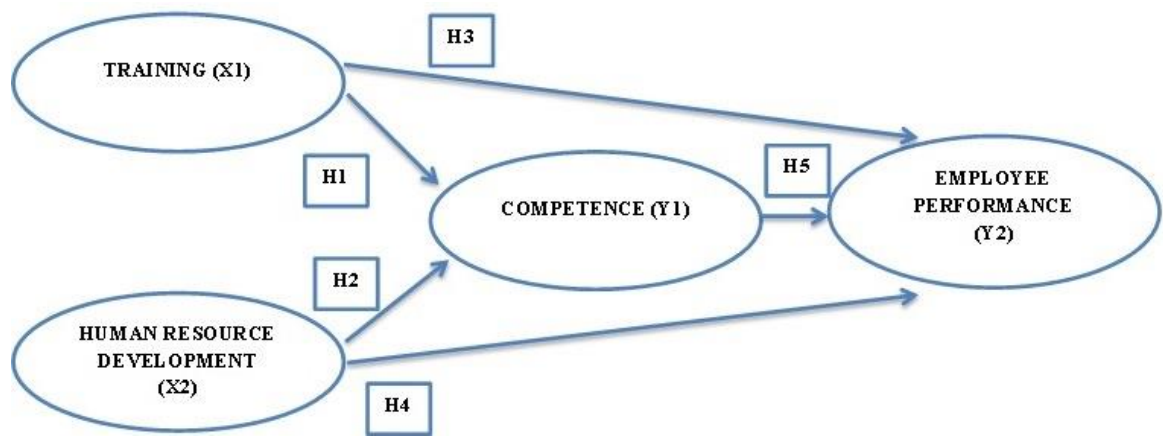

Source: Researchers (2019)

\section{Hypothesis}

H1: There is a direct influence between Training on Competence.

H2: There is a direct influence between Human Resource Development on Competence.

H3: There is a direct influence between Training on Employee Performance.

H4: There is a direct influence between Human Resource Development on Employee Performance.

H5: There is a direct influence between Competence on Employee Performance.

\section{RESEARCH METHODOLOGY}

\section{Type of Research}

The type of research used is using a quantitative approach.

\section{Population, Sample and Sampling Technique}

In this study the population was employees of the Syahbandar Office. With a population of 222 employees. Because the population in this study is known, then for sampling from the population proposed Slovin formula. Then the sample will be used by researchers, amounting to 143 respondents.

\section{Types and Sources of Data}

Types of data from this study are quantitative data. Quantitative data obtained in the form of the results of the assessment obtained from the questionnaire in the form of scoring questions granules that can be processed and analyzed for answers to problem problems. Data Sources namely Primary data, the source of data from this study is primary data. Primary data in the form of data obtained from questionnaires through answers directly from respondents and through direct observation of the object. Secondary data, the source of data from this study is secondary data. Secondary data of this study in the form of data from books and interviews with employees of the Syahbandar Office.

\section{Data Collection Techniques The Data Collection}

Technique of this study is to use the questionnaire method Scale measurement data in this study can be measured using the Likert scale method. The following is how to measure using the Likert scale: 
1. Score 1: Strongly Disagree (STS)

2. Score 2: Disagree (TS)

3. Score 3: Simply Agree (CS)

4. Score 4: Agree (S)

5. Score 5: Strongly Agree (SS)

II. Research Results and Discussion

Path Coefficient

\begin{tabular}{|c|c|c|c|c|c|}
\hline & $\begin{array}{c}\text { Original Sample } \\
(\mathrm{O})\end{array}$ & $\begin{array}{c}\text { Sample Mean } \\
(\mathrm{M})\end{array}$ & $\begin{array}{c}\text { Standard Deviation } \\
\text { (STDEV) }\end{array}$ & $\begin{array}{c}\text { T Statistics (| O / STDEV } \\
\mid) \\
\end{array}$ & $\begin{array}{c}\mathbf{P} \\
\text { Values }\end{array}$ \\
\hline $\begin{array}{c}\mathrm{X} 1 \text {-> } \\
\text { Y1 }\end{array}$ & 0.265 & 0.262 & 0.065 & 4,091 & 0,000 \\
\hline $\begin{array}{l}\text { X1 -> } \\
\text { Y2 }\end{array}$ & 0.274 & 0.274 & 0.052 & 5.273 & 0.000 \\
\hline $\begin{array}{c}\text { X2 -> } \\
\text { Y1 }\end{array}$ & 0.712 & 0.714 & 0.062 & 11,494 & 0,000 \\
\hline $\begin{array}{l}\mathrm{X} 2-> \\
\mathrm{Y} 2\end{array}$ & 0.399 & 0.407 & 0.086 & 4,614 & 0,000 \\
\hline $\begin{array}{c}\text { Y1 -> } \\
\text { Y2 }\end{array}$ & 0.189 & 0.181 & 0.103 & 1.835 & 0.034 \\
\hline
\end{tabular}

1. Effect of Training on Competence

Based on the results of analysis using SmartPLS, it can be concluded that Training has a significant effect on Competence. With the results of hypothesis testing the value of $\mathrm{p}$-value is 0,000 and the value of $\mathrm{t}$ is 4,091 . This value is greater than $t$ table (1.65) and p-value below 0.05 . Thus, H1 in this study was accepted. This shows that the existence of Training at the Syahbandar Office can achieve employee competency.

2. The Effect of Human Resource Development on Competence

Based on the results of the analysis using SmartPLS it can be concluded that Human Resource Development has a significant influence on Competence. With the results of hypothesis testing the value of p-value is 0,000 with a $t$ value of 11,494 . This value is greater than $\mathrm{t}$ table (1.65) and $\mathrm{p}$-value below 0.05 . Thus, $\mathrm{H} 2$ in this study was accepted. This shows that with the development of Human Resources at the Office of the Shahbandar, employees will gain new abilities, skills and expertise, thereby increasing Competence as well.

3. The Effect of Training on Employee Performance

Based on the results of the analysis using SmartPLS it can be concluded that Training has a significant influence on Employee Performance. With the results of hypothesis testing the value of p-value 0,000 with a $t$ value of 5,273. This value is greater than $\mathrm{t}$ table (1.65) and $\mathrm{p}$-value below 0.05 . Thus $\mathrm{H} 3$ in this study was accepted. This shows that with good and programmed training can produce quality employee performance.

4. Effects of Human Resource Development on Employee Performance

Based on the results of the analysis using SmartPLS, it can be concluded that Human Resource Development has an influence on Employee Performance. With the results of hypothesis testing the value of p-value 0,000 with a value of $t$ equal to 4,614. This value is greater than $t$ table (1.65) and p-value below 0.05 . Thus, H3 in this study was accepted. This shows that the existence of Human Resource Development can improve Employee Performance.

5. The Effect of Competence on Employee Performance

Based on the results of the analysis using SmartPLS it can be concluded that Competence has an influence on Employee Performance. With the results of hypothesis testing the $\mathrm{p}$-value is 0.034 with a t value of 1.835 . This value is greater than $\mathrm{t}$ table (1.65) and p-value below 0.05 . Thus, $\mathrm{H} 3$ in this study was accepted. This shows that the existence of Competence can improve Employee Performance. Because in essence the competence is very necessary to help create high performance.

\section{CONCLUSIONS}

\section{Conclusions}


1. The results of data processing indicate a significant influence between the Training variable (X1) on Competence (Y1). With the results of hypothesis testing the value of p-value is 0,000 and the value of $t$ is 4,091. With the results of these data, this shows that the presence of Training at the Syahbandar Office can achieve employee competency.

2. The results of data processing indicate a significant influence between the variables of Human Resource Development (X2) on Competence (Y1). With the results of hypothesis testing the value of p-value is 0,000 with a $t$ value of 11,494 . With the results of these data, this shows that the existence of Human Resource Development in the Syahbandar Office employees will gain new abilities, skills and expertise, thereby increasing Competence as well.

3. The results of data processing indicate a significant influence between Training variables (X1) on Employee Performance (Y2). With the results of hypothesis testing the value of p-value 0,000 with a $t$ value of 5,273. With the results of these data it shows that with good and programmed training can produce quality employee performance.

4. The results of data processing indicate a significant influence between the variables of Human Resource Development (X2) on Employee Performance (Y2). With the results of hypothesis testing the value of pvalue 0,000 with a value of $\mathrm{t}$ equal to 4,614. With the results of these data it shows that the presence of Human Resource Development can improve Employee Performance.

5. The results of data processing indicate a significant influence between the Competency variable (Y1) on Employee Performance (Y2). With the results of hypothesis testing the p-value is 0.034 with a t value of 1.835. With the results of these data, this shows that the presence of Competence can improve Employee Performance.

\section{REFERENCES}

Adolfina, Lolowang, M. G. and Lumintang, G. (2016) 'PENGARUH PELATIHAN DAN PENGEMBANGAN SUMBER DAYA MANUSIA TERHADAP KINERJA KARYAWAN PADA PT. BERLIAN KHARISMA PASIFIK MANADO', Jurnal EMBA, 4(2), pp. 177-186.

Amir, D. M. F. (2015a) MEMAHAMI EVALUASI KINERJA KARYAWAN Konsep dan Penilaian Kinerja di Perusahaan. Edisi Asli. Jakarta: Mitra Wacana Media.

Amir, D. M. F. (2015b) MEMAHAMI EVALUASI KINERJA KARYAWAN Konsep dan Penilaian Kinerja di Perusahaan. Jakarta: Mitra Wacana Media.

Amir, D. M. F. (2015c) MEMAHAMI EVALUASI KINERJA KARYAWAN Konsep dan Penilaian Kinerja di Perusahaan. Edisi Asli. Jakarta: Mitra Wacana Media.

Athar, R. and Shah, F. M. (2015) 'Impact of Training on Employee Performance ( Banking Sector Karachi )', 17(11), pp. 58-67. doi: 10.9790/487X-171115867.

Efendi, N. (2017) 'Pengembangan Sumberdaya Manusia Berbasis Kompetensi di Kantor Pemerintah Kota Bandar Lampung', MIMBAR, Jurnal Sosial dan Pembangunan, 31(1), p. 1. doi: 10.29313/mimbar.v31i1.839.

Fernandes, D. A. A. R. and Solimun, D. I. (2016) PEMODELAN STATISTIKA PADA ANALISIS RELIABILITAS DAN SRVIVAL. Edited by T. U. Press. Malang: UB Press.

Findarti, F. R. (2016) 'PENGARUH PENGEMBANGAN SUMBER DAYA MANUSIA TERHADAP KINERJA PEGAWAI PADA KANTOR BADAN KEPEGAWAIAN DAERAH PROVINSI KALIMANTAN TIMUR', e-Journal Ilmu Administrasi Bisnis, 4(5), pp. 937-946.

Ghozali (2015) Partial Least Square.

Handoko, T. H. (2001a) MANAJEMEN PERSONALIA DAN SUMBERDAYA MANUSIA Edisi 2. Edisi Kedu. Edited by BPFE-YOGYAKARTA. Yogyakarta.

Handoko, T. H. (2001b) MANAJEMEN PERSONALIA DAN SUMBERDAYA MANUSIA Edisi 2. Edisi Kedu. Yogyakarta: BPFE-YOGYAKARTA.

Imran, M. and Tanveer, A. (2015) 'IMPACT OF TRAINING \& DEVELOPMENT ON EMPLOYEES ' PERFORMANCE IN BANKS OF PAKISTAN', European Journal of Training and Development Studies, 3(1), pp. 22-44.

Mangkunegara, D. A. A. A. P. (2003) Perencanaan dan Pengembangan SUMBER DAYA MANUSIA. Edited by P. D. H. L. Rasjidi and A. Gunarsa. Bandung: PT Refika Aditama.

Martini, I. A. O. et al. (2018) 'The Influence of Competency on Employee Performance through Organizational Commitment Dimension', IOSR Journal of Business and Management (IOSR-JBM), 20(2), pp. 29-37. doi: 10.9790/487X-2002082937. 
Masram, D. H. and Mu'ah, D. H. (2015) Manajemen Sumber Daya Manusia. Sidoarjo: Zifatama Publisher.

Masram, D. H. and Mu'ah, D. H. (2017a) Manajemen Sumber Daya Manusia Profesional. Sidoarjo: Zifatama Publisher.

Masram, D. H. and Mu'ah, D. H. (2017b) MANAJEMEN SUMBER DAYA MANUSIA PROFESIONAL. Sidoarjo: Zifatama Publisher.

Ningrum, A. C. (2017) PENGARUH PELATIHAN DAN PENGEMBANGAN SUMBER DAYA MANUSIA TERHADAP KINERJA KARYAWAN PT. BRI KANTOR CABANG SURABAYA DIPONEGORO MELALUI KOMPETENSI. Surabaya.

Nyoto, D. (2019) Manajemen Sumber Daya Manusia. Edited by Asrizal. Ponorogo: Uwais Inspirasi Indonesia.

Panggabean, D. M. S. (2004a) MANAJEMEN SUMBER DAYA MANUSIA. Edited by Sofyan and Lolita. Bogor: Ghalia Indonesia.

Panggabean, D. M. S. (2004b) MANAJEMEN SUMBER DAYA MANUSIA. Edited by Sofyan and Lolita. Bogor: Ghalia Indonesia.

Pranata, O. S., Astuti, E. S. and Utami, H. N. (2018) 'PENGARUH PELATIHAN TERHADAP KOMPETENSI DAN KINERJA KARYAWAN (Studi pada karyawan tetap di PT Bank Tabungan Pensiunan Nasional Syariah Malang Divisi Mobile Marketing Syariah) Okky', Jurnal Administrasi Bisnis (JAB), 61(3).

Rahinnaya, R. and Perdhana, M. S. (2016) 'ANALISIS PENGARUH PELATIHAN DAN PENGEMBANGAN, KOMPENSASI SERTA KOMPETENSI TERHADAP KINERJA KARYAWAN (Studi Pada PT. Pos Semarang)', Diponegoro Journal Of Management, 5(3), pp. 1-11.

Riniwati, H. (2016a) MANAJEMEN SUMBER DAYA MANUSIA: Aktivitas Utama dan Pengembangan SDM. Edited by T. U. Press. Malang: Universitas Brawijaya Press.

Riniwati, H. (2016b) MANAJEMEN SUMBER DAYA MANUSIA Aktivitas Utama dan Pengembangan SDM. Edited by T. U. Press. Malang: Universitas Brawijaya Press.

Simanjustak, P. D. P. J. (2011) MANAJEMEN \& EVALUASI KINERJA. Jakarta: Fakultas Ekonomi Universitas Indonesia.

Sriekaningsih, A. and Setyadi, P. D. (2015) 'The Effect of Competence and Motivation and Cultural Organization towards Organizational Commitment and Performance on State University Lecturers in East Kalimantan Indonesia', European Journal of Business and Management, 7(17), pp. 208-220.

Sudaryo, D. Y., Aribowo, D. A. and Dr. Nunung Ayu Sofiati (2018) MANAJEMEN SUMBER DAYA MANUSIA, KOMPENSASI TIDAK LANGSUNG DAN LINGKUNGAN KERJA FISIK. Edited by T. Erang. Yogyakarta: ANDI.

Sulaksono, H. (2019) BUDAYA ORGANISASI DAN KINERJA. Yogyakarta: DEEPUBLISH.

Wirawan (2015a) Evaluasi Kinerja Sumber Daya Manusia Teori, Aplikasi, dan Penelitian. Jakarta: Salemba Empat. Wirawan (2015b) Evaluasi Kinerja Sumber Daya Manusia Teori, Aplikasi, dan Penelitian. Jakarta: Salemba Empat.

Yang, J., Fang, S. and Huang, C. (2017) 'The Mediating Role of Competency on the Relationship between Training and Task Performance : Applied Study in Pharmacists', International Journal of Business Administration, 8(7), pp. 16-24. doi: 10.5430/ijba.v8n7p16. 